\title{
SANKSI ADAT TERHADAP PERKAWINAN EXOGAMI \\ DI DESA PAKRAMAN TENGANAN PENGRINGSINGAN, KECAMATAN MANGGIS, KABUPATEN KARANGASEM, PROVINSI BALI
}

\author{
I Putu Sudarma \\ Pande Kadek Dharmajayanti
}

\section{Program Pascasarjana Institut Hindu Dharma Negeri Denpasar \\ E-mail : iputusudarma8@gmail.com}

\begin{abstract}
Abstrak
Masyarakat Desa Adat Tenganan Pegrisingan, Desa Tenganan, Kecamatan Manggis, Kabupaten Karangasem, Provinsi Bali tergolong masyarakat Bali-Aga yang masih kental dengan larangan adat pada perkawinan exogami. Pelanggaran atas larangan perkawinan tersebut dikenakan sanksi adat. Sanksi adat tidak hanya dikenakan kepada kedua mempelai, tetapi juga orang tua mempelai di desa tersebut.

Sanksi dalam perkawinan eksogami di Desa Pakraman Tenganan Pegringsingan dikenakan dengan alasan, yaitu pelestarian tradisi, sistem kekerabatan, dan menjaga kesehimbangan. Bentuk sanksi adat dalam perkawinan eksogami berupa sanksi denda dan sanksi moral, sedangkan implikasinya adalah menunjukkan ketidakemansipasian dalam perkawinan, dan kehilangan semua haknya sebagai krama desa di Desa Pakraman Tenganan Pegringsingan.
\end{abstract}

Key word: sanksi adat, perkawinan exogami.

\section{Abstract}

Indigenous Village Community of Tenganan Pegrisingan, Tenganan Village, Manggis District, Karangasem Regency, Bali Province is classified as a Balinese-Aga community which is still thick with customary prohibitions on exogami marriage. Violations of the marriage ban are subject to customary sanctions. Customary sanctions are not only imposed on the bride and groom, but also the bride's parents in the village.

Sanctions in exogamous marriages in Pakraman Village, Tenganan Pegringsingan are subject to reason, namely preservation of traditions, kinship system, and maintaining health. The form of customary sanctions in exogamy marriage is in the form of fines and moral sanctions, while the implication is to show inconsistency in marriage, and lose all of their rights as village manners in Pakraman Tenganan Pegringsingan Village.

Key word: custom sanction, exogami marriage.

\section{Pendahuluan}

Dalam konteks sosial budaya terutama dalam fenomena perkawinan, masyarakat mengenal adanya dua model perkawinan, yaitu model endogami dan eksogami. Clayton (1975: 45) mengemukakan bahwa ada dua jenis aturan yang berhubungan dengan perkawinan, yaitu

“ (a) endogamy which refers to rules prescribing that an individual must marry some one within a certain group, and (b) 
exogamy, which requirest that a person marry some one outside of acertain group".

Model perkawinan endogami mencerminkan preferensi individu kawin dalam kelompok mereka sendiri. Model perkawinan ini telah secara luas dipraktekan di dalam banyak masyarakat dan dipergunakan dalam berbagai kelompok salah satu di antaranya sistem kasta di India yang mengharuskan perkawinan terjadi secara endogami. Di Eropa pada abad pertengahan, keluarga raja kawin dengan keluarga raja lainnya. Tidak terkecuali di Amerika Serikat, seorang kulit hitam kawin dengan kulit hitam, orang kulit putih kawin dengan kulit putih dan orang Yahudi menunjukkan preferensi yang sangat kuat untuk kawin dengan sesama orang Yahudi (Sanderson, 1993 : 448-449; Andreski, 1996 : 92).

Model perkawinan endogamy juga pernah berlaku pada zaman kerajaan di Bali. Mereka harus melakukan perkawinan dengan sesama wangsa atau kastanya sendiri. Pelanggaran atas larangan perkawinan ini dikenakan sanksi adat asupundung dan alangkahi karang hulu. Asupundung adalah delik adat perkawinan antara perempuan brahmanawangsa dan laki-laki sudrawangsa. Sebaliknya, alangkahi karang hulu adalah sanksi adat perkawinan antara perempuan kesatriawangsa dan laki-laki sudrawangsa. Semua perkawinan antara perempuan berkasta lebih tinggi dengan laki-laki berkasta lebih rendah di Bali dihukum mati dengan hukuman labuh batu, dan labuh geni. Krepun (Wiana, 2006 :161162) menyatakan bahwa jika terjadi perkawinan antara perempuan yang berkasta lebih tinggi dengan laki-laki yang berkasta lebih rendah, kedua mempelai dihukum mati dengan hukuman labuh geni dan labuh batu. Labuh geni adalah hukuman mati dengan cara membakar hidup-hidup mempelai perempuan, sedangkan labuh batu adalah hukuman mati untuk mempelai laki dengan menenggelamkannya ke laut setelah kakinya diberi pemberat batu hingga tewas. Friederich (1959 : 101-102) dalam bukunya yang berjudul
"The Civilization and Culture of Bali" kekejaman kedua hukuman tersebut sebagai berikut.

".....in Bali,all marriage of high-caste women with men of lower birth (provided they bare acknowledged) are punished with death. The guitly women is burned alive. A hole is made in the ground and with combustibbles, into which the women is cast. This punishment is called labuh geni (to faal or to be cast into the fire). The man is weigted with stone and drowned in the sea. This is called labuh batu. This penalty, especially the burning of the women,is not always carried out so relentlessly. In several cases which came to my knowledge both the man and the women were drowned. In another case, where the man had escaped vengeance by flight. The women, at the command of the father (a Gusti in Kuta), was killed with the creese by a relation her's brother, after being adorned with flowers and fine clethes, and rendered fearless by opiun and strong drink".

Kutipan di atas menunjukkan bahwa penerapan sanksi adat pada perkawinan antarwangsa tidak selalu dilakukan dengan hukuman labuh gni, tetapi juga dapat dilaksanakan dengan cara ditikam dengan keris.

Wiana dan Santri (1993:110) mengemukakan bahwa sistem pelapisan masyarakat (kasta) merupakan salah satu aspek penting tentang perkawinan umat Hindu di Bali. Pengertian kasta pada hakikatnya tidak dikenal di dalam kitab suci Hindu karena sistem kasta akan menempatkan posisi dan kedudukan manusia dalam masyarakat pada strata yang lebih tinggi atau lebih rendah. Sebaliknya, sistem pelapisan sosial yang dikenal dalam agama Hindu disebut dengan istilah warna yang berkaitan dengan profesi atau fungsi individu dalam masyarakat. Walaupun demikian, tetapi dalam realita sosial istilah catur warna lebih dikenal dengan nama catur wangsa yang terdiri atas brahmana wangsa, kesatria wangsa, wesya wangsa dan sudra wangsa. Brahmana wangsa, kesatria wangsa, wesia wangsa disebut 
triwangsa, sedangkan sudra wangsa dinamakan jaba wangsa. Pengertian kasta ini tumbuh karena penguasaan dan penghayatan agama yang belum secara utuh.

Mantra (Budiana, 2004 : 4) mengatakan bahwa unsur-unsur dasar catur warna ada pada setiap orang, yaitu (1) orang akan menjadi brahmana jika lebih kuat pengaruh atau bakat kerohaniannya. (2) orang akan menjadi ksatria jika yang lebih dominan pertumbuhan bakatnya dalam kepemimpinan. (3) orang akan menjadi waisya jika yang lebih dominan pertumbuhan bakatnya dalam bidang ekonomi. (4) orang yang mampu menumbuhkan tenaga fisiknya akan menjadi sudra.

Geertz (Dharmayuda, 2001 : 40) mengemukakan bahwa brahmana wangsa, dan ksatria wangsa adalah golongan yang sangat dihormati dalam masyarakat adat di Bali sehingga disebut gentry (golongan terhormat), sedangkan jaba wangsa disebut commoners (orang-orang biasa, kebanyakan). Penghormatan kepada golongan gentry tidak saja pada zaman kerajaan, tetapi berlanjut hingga sekarang. Hal itu dapat dilihat dalam kehidupan bermasyarakat, yaitu masih kuatnya ikatan siwa-sisya, gusti-panjak.

Setelah zaman kerajaan walaupun pemeritahan kerajaan tidak ada lagi, tetapi unsur kewangsaan masih tetap merupakan struktur di dalam masyarakat Bali. Hak-hak kewangsaan dapat dikatakan tidak hanya hak keperdataan, yaitu hanya menjadi urusan kekerabatan dari wangsa yang bersangkutan, tetapi juga merupakan persoalan adat karena adat Bali masih mengakui keberadaan dan tetap memperhatikan kedudukannya berdasarkan prinsip linggih (kedudukan, seseorang dalam masayarakat) dan sesana (kewajiban) (Dharmayuda, 2001 : 41).

Seiring dengan perkembangan zaman dan meningkatnya peradaban manusia, sanksi adat asupundung dan alangkahikarang hulu dicabut tahun 1951 oleh pemerintah Bali karena dianggap sangat kejam dan biadab. Walaupun telah dicabut, tetapi perkawinan antarwangsa di Bali masih memperlihatkan perlakuan diskriminatif walaupun tidak sekejam zaman kerajaan (Sudarma, 2015 : 161).

Perkawinan di Desa Adat Tenganan Pegrisingan, Karangasem perlakuannya hampir sama dengan perkawinan antarwangsa di Bali. Perlanggaran atas larangan perkawinan berbeda warga desa adat walaupun sama-sama beragama Hindu mendapat perlakuan diskriminatif berupa sanksi adat. Sanksi adat yang dikenakan tidak hanya dirasakan oleh kedua mempalai, tetapi juga orang tua mempelai.

Fenomena perkawinan antarwarga berbeda desa adat di Desa Adat Tenganan Pegringsingan Bali menarik untuk diungkapkan karena sanksi atas pelanggaran perkawinan antarwarga berbeda desa adat tidak hanya bertentangan dengan nilainilai kemanusiaan, ajaran agama, tetapi juga undang-undang perkawinan di Indonesia.

\section{Alasan-alasan Yang Mendorong Penerapan Sanksi Adat Pada Perkawinan Eksogami}

\subsection{Pelestarian Tradisi}

Pulau Bali yang mayoritas penduduknya beragama Hindu memiliki beragam tradisi, salah satu di antaranya adalah tradisi pernikahan. Covarrubias (2013:147-161) menyatakan bahwa adat pernikahan masing-masing kabupaten di Bali berbeda-beda. Sering yang dianggap biasa pada satu desa, tidak terjadi pada desa yang lain karena tidak ada aturan umum yang dapat ditegakkan atau diterapkan di seluruh pulau Bali. Seorang laki-lakipun tidak terikat secara moral untuk bersetia dengan adat istrinya, sedangkan ketidaksetiaan dari pihak perempuan dianggap suatu kejahatan yang mengerikan, dan dihukum secara sah pada masa lalu dengan kematian dari pasangan yang bersalah.

Perkawinan pada era globalisasi di Bali menunjukkan adanya keterbukaan daripada 
sebelumnya. Perkawinan tidak hanya terjadi antarwangsa, lintas agama, tetapi juga berbeda kewarganegaran. Akan tetapi berbeda dengan perkawinan di Tenganan Pegringsingan. Masyarakat desa adat ini kental dengan tradisi perkawinan endogamy, sedangkan perkawinan eksogami sangat dilarang bahkan dikenai sanksi adat bagi warganya yang melanggar. Dengan penerapan saksi adat, masyarakat Desa Adat Tenganan Pegringsingan masih terkukung oleh tradisi perkawinan yang bernuansa diskriminatif. Warganya tidak boleh melakukan perkawinan eksogami kecuali perkawinan endogamy antar sesame warga adatnya sendiri. Warganya khawatir dan takut melakukan perkawinan eksogami karena di desanya terdapat nilai-nilai cultural yang sangat sulit dirubahnya. Mereka masih terikat dngan konsepsi yang berarkar pada nilainilai budaya tradisional yang menilai perkawinan endogamy sebagai perkawinan yang paling ideal bahkan dianggap perkawinan terhormat. Di desa adat ini hanya warganya melakukan perkawinan endogamy yang mempunyai hak istimewa di desa adatnya. Keistimewaan hak dimaksud adalah hak sebagai krama desa. Tanpa menjadi mkrama desa, mereka tidak boleh duduk dalam struktur sosial, mengikuti sangkepan (rapat) di Bale agung untuk ikut membuat keputusan desanya. Sebaliknya, dinilai rendah jika melakukan perkawinan eksogami karena semua hak-haknya dicabut termasuk hak untuk tinggal di desa adatnya.

Menurut Timur sebagai matan kliang (ketua) desa adat Tenganan Pegringsingan menyatakan bahwa tradisi yang lainnya yang harus ditaati warganya sebelum melakukan perkawinan, yaitu maajak-ajakan, dan metruna nyoman. Maajakajakan yakni pendaftaran diri oleh warganya yang baru naik dewasa baik warganya yang laki-laki maupun perempuan untuk ikut dalam metruna nyoman. Sebaliknya, metruna nyoman adalah organisasi tradisional pemuda di Desa Adat Tenganan Pegringsingan. sebagai anggota metruna nyoman bagi warganya yang laki-laki, dan sekaa daha bagi warganya yang perempuan.

Matruna nyoman wajib dilakukan oleh semua warganya yang belum menikah. Jika di antara warganya melakukan perkawinan, tetapi belum maajak-ajakan dan matruna nyoman, mereka akan dikenai sanksi adat. Sementara pembinaannya dilakukan di asrama selama satu tahun dan waktu pelaksanaannya tiap-tiap hari pada malam hari dari pukul 1700 mhingga pukul 19 00. Materi pembinaannya berkaitan dengan berbagai tradisi, peraturan, dan upacara keagamaan di desanya.

Lodri sebagai istri mantan Kliang Desa Tenganan Pegringsingan menyatakan bahwa maajak-ajakan dan metruna nyoman menempati peranan penting dalam perkawinan di desanya. Bagi warganya yang belum pernah mengikuti maajak-ajakan dan metruna nyoman, tetapi melakukan perkawinan dianggap melanggar awigawig desanya. Pelanggaran tersebut dikenai sanksi adat yang sama saksinya dengan pelanggaran atas larangan perkawinan eksogami. Semua hak-hak mempelai dicabut, dan dikeluarkan atau diusir dari desanya. Kedua mempelai dianggap telah melanggar awig-awig, dan mengotori palemahan (alam lingkungannya) dan pawongan (warga mayarakat). Ketidaksehimbangan desanya sebagai akibat perkawinan eksogami dapat dikembalikan seperti semula melalui sanksi adat pencabutan semua hak-haknya termasuk hak tinggal di desanya. Dengan dikeluarkan dari desanya, keletehan yang mengganggu desanya diyakini kesehimbangan desanya bisa pulih kembali. Senada dengan Lodri, Putu Yudiana sebagai kepala Desa Tenganan mengatakan bahwa mempelai pada saat mengikuti masa gerhasta (berumah tangga) kedua mempelai tidak sulit beradaptasi dengan pasangannya dan keluarganya masing-masing karena mereka telah saling mengenal sejak anak-anak, bersama-sama mengikuti sistem pembelajaran di pasraman, dan bersama-sama ikut dalam organisasi metruna nyoman. Akan tetapi sangat berbeda jika salah satu di antara mempelai berasal dari luar Desa Pakraman Tenganan Pegringsingan (perkawinan 
eksogami) yakni mereka sangat sulit beradaptasi dan memahami berbagai tradisinya karena tidak pernah mengikuti pembinaan di desa tersebut.

\subsection{Sistem Kekerabatan}

Hidup individu pada masyarakat di dunia hampir semuanya dibagi oleh adat masyarakatnya ke dalam tingkat-tingkat tertentu. Tingkatantingkatan sepanjang hidup individu dalam antropologi sering disebut stage along the lifecycle. Tingkat-tingkat hidup tersebut seperti masa bayi, masa penyapihan, masa kanak-kanak, masa remaja, masa pubertet, masa setelah nikah, masa hamil, masa tua dan lain sebaginya. Salah satu saat peralihan yang terpenting pada life cycle dari semua manusia di seluruh dunia adalah saat peralihan dari tingkat hidup remaja ke tingkat hidup berkeluarga (perkawinan). Perkawinan tidak hanya pengatur kelakuan sex, tetapi juga mempunyai berbagai fungsi lainnya. Fungsifungsi yang dimaksud, yaitu (1) memberi ketentuan hak dan kewajiban dan perlindungan kepada anak-anak hasil persetubuhannya. (2) memenuhi kebutuhan manusia akan seorang teman hidup, memenuhi kebutuhan akan harta, dan (3) pemeliharaan hubungan antara kelompokkelompok kerabat (Koentjaraningrat, 1992 : 9394).

Tiap-tiap banngsa di dunia terdiriatas beraneka ragam suku bangsa, agama, dan hukum adat yang satu dengan yang lainnya berbeda. Hukum adat adalah hukum yang timbul dan terdapat masyarakat. Hukum adat terdiri atas kumpulan norma-norma berisikan kaedah-kaedah hukum yang dibuat dengan sengaja oleh masyarakat. Dengan demikian, hukum adat dapat dipandang sebagai cerminan aspek-aspek keraohanian suatu masyarakat yang berkaitan erat dengan susunan kehidupan masyarakat. Salah satu yang di atur masyarakat adalah tentang sistem kekerabatan. Para ahli menyatakan bahwa paling sedikit ada empat prinsip kekerabatan. Keempat prinsip kekekrabtan tersebut, yaitu (1) prinsip patrilineal (patrilineal descent) adalah kekerabatan yang menghitungkan hubungan kekerabatan melalui pria saja.Tiap individu dalam masyarakat semua kaum kerabat ayahnya masuk dalam hubungan kerabatanya, sedangkan kerabat ibunya berada di luar batas kerabat tersebut. (2) Prinsip matrilineal (matrilineal descent) adalah kekerabatan yang menghitungkan hubungan kekerabatan melalui ibu saja. Tiap individu dalam masyarakat semua kerabat ibunya masuk dalam batas hubungan kekerabatannya, sedangkan semua kaum kerabat ayahnya berada berada di luar batas tersebut. (3) Prinsip bilinial (bilinial descent) adalah kekerabatan yang menghitungkan hubungan kekerabatan melalui peria saja untuk sejumlah hak dan kewajiban tertentu, dan melalui wanita saja untuk sejumlah hak dan kewajiban yang lain, dan (4) Prinsip bilateral (bilateral descent) adalah kekerabatan yang menghitungkan hubungan kekerabatan melalui ayah maupun wanita. Semua kaum kerabat ibu maupun ayah masuk dalam dalam hubungan kekerabatannya sehingga tidak ada batas sama sekali (Koentjaraningrat, 1992 : 135).

Budiana (2008 : 11) menyatakan bahwa perkawinan sulit dipahami tanpa memahami sistem kekeluarga kekerabatan. Masyarakat Hindu di Bali sebagaimana masyarakat umumnya di Indonesia, menganut sistem kekerabatan patrilineal. Sistem kekerabatan ini didasari garis keturunan yang ditarik melalui pihak laki-laki. Dengan sistem kekekrabatan patrilineal, peran anak laki-laki sangat penting baik dalam hubungan dengan kekeluargaan maupun dalam hubungan kemasyarakatan. Dalam hubungan kekeluargaan, anak laki-laki berperan sebagai penerus keturunan, hak, dan kewajiban dalam keluarga. Anak lakilaki mempunyai hak mewarisi harta kekayaan orang tuanya dan mempunyai kewajiban dalam pemeliharaan tempat suci keluarga. Kewajiban lainnya adalah melaksanakan upacara pitra yadnya (upacara kematian). Sebaliknya, dalam konteks hubungan kemasyarakatan, peran anak laki-laki 
tampak lebih menonjol sebagai krama (anggota) di banjar atau desa pakraman.

Di Bali masyarakat tidak dipandang sebagai badan yang terpisah dari individu dan golongan, tetapi merupakan bagian dari masyarakat. Maksudnya, masyarakat mengakui hak-hak individu dan individu mengakui hakhak masyarakat sebagai suatu kepentingan bersama. Dalam sistem nilai masyarakat Bali terdapat pandangan yang menilai tinggi suatu kehidupan jika didasarkan atas asas kebersamaan, asas kekeluargaan, dan asas berbakti. Ketiga asas tersebut bersumber pada pandangan hidup masyarakat bahwa manusia tidak hidup sendiri di dunia, tetapi dikelilingi oleh komunitasnya, masyarakat, dan alam sekitarnya. Asas kebersamaan dapat mendorong manusia untuk berorientasi kepada sesamanya, asas kekeluargaan mendorong manusia mewujudkan persatuan dan kesatuan, serta asas berbakti menumbuhkan loyalitas untuk mengabdi. Rasa bakti masyarakat Bali diwujudkan dalam bentuk yadnya (korban suci) yang ditujukan ke hadapan Hyang Widhi (Tuhan) (Majelis Pembina Lembaga Adat Daerah Tingkat I Bali, 1992/1993 : 9).

Putu Yudiana menyatakan bahwa masyarakat Tenganan Pegringsingan tidak mengenal sistem kekerabatan berdasarkan kasta. Akan tetapi di desa ini berlaku sistem kekerabatan bilateral. Jika terjadi perkawinan, kedua mempelai berhak menjadi ahli waris. Hak dan kedudukan antara anak laki-laki dan perempuan sama dimata hukum. Dengan sistem kekerabatan ini juga seorang ego mengenal keluarga luas. Maksudnya, seorang ego mengenal hubungan mereka dengan sanak saudara dari pihak ibu maupun dari pihak ayah. Di samping itu, hubungan kekerabatan menjadi sangat erat karena pihak suami dan istri masih memiliki hubungan darah. Sistem kekerabatan bilateral di Desa Adat Tenganan Pegringsingan bahwa kesatuan dan keutuhan kebudayaan tetap terjaga dan terpelihara karena kedua pihak mempelai memiliki tanggung jawab yang sama baik keluarga maupun masyarakat. Sebaliknya, kekerabatannya dicabut dan hilang di desa ini jika warganya melakukan perkawinan eksogami. Dengan demikian, warganya agar tetap menjadi kerabatanya di desanya harus melakukan perkawinan endogamy. Jika warganya melakukan pelanggaran atas larangan perkawinan eksogami, konskuensinya kekerabatannya hilang karena dicabut oleh desanya bahkan haknya dicabu untuk tinggal di Desa Pakraman Pegringsingan. Hal ini dilakukan untuk menjaga dan mempertahankan tradisi adat terutama system kekerabtan bilateral. Sistem kekerabatan ini di Desa Tenganan Pegringsingan kedua pihak mempelai sama-sama mendapatkan pembagian waris dari orang tuanya. Di samping itu juga dapat menjadi krama desa dan pembagian karang desa untuk mendirikan rumah bagi warganya yang baru melakukan perkawinan.

\subsection{Menjaga Kesehimbangan}

Manusia dalam hidupnya tidaka hanya sebagai makhluk individu, tatapi juga sebagai makhluk sosial. Dalam kapasitasnya sebagai makhluk sosial, manusia tidak dapat hidup dalam kesendirian tanpa bantuan orang lain sehingga sikap tolong-menolong dan kesetiakawanan sangat dibutuhkan. Hal ini memberikan kewajiban untuk memperhatikan keperluan-keperluan sesamanya. Koentjaraningrat (1992:55) menyatakan bahwa setiap manusia yang hidup dalam masyarakat akan terikat oleh suatu bentuk kesatuan sosial karena adanya ikatan wilayah atau tempat kehidupan. Sebagai suatu kesatuan hukum sosial, warga masyarakat biasanya mempunyai perasaan kesatuan yang dapat mewujudkan rasa kepribadian kelompok.

Di Bali masyarakat tidak dipandang sebagai badan yang terpisah dari individu dan golongan, tetapi merupakan bagian dari masyarakat. Maksudnya, masyarakat mengakui hak-hak individu dan individu mengakui hak-hak masyarakat sebagai suatu kepentingan bersama. Masyarakat Bali juga memiliki pandangan yang 
menilai tinggi suatu kehidupan jika didasarkan atas asas kebersamaan, asas kekeluargaan, dan asas berbakti. Ketiga asas tersebut bersumber pada pandangan hidup masyarakat bahwa manusia tidak hidup sendiri di dunia, tetapi dikelilingi oleh komunitasnya, masyarakat, dan alam sekitarnya. Asas kebersamaan dapat mendorongmanusiauntuk berorientasi kepada sesamanya, asas kekeluargaan mendorong manusia mewujudkan persatuan dan kesatuan, serta asas berbakti menumbuhkan loyalitas untuk mengabdi. (Majelis Pembina Lembaga Adat Daerah Tingkat I Bali, 1992/1993 : 9). Pandangan hidup masyarakat Bali tersebut juga di Desa Adat tenganan Pegringsingan yang dipandang dapat menggerakkan dan mewujudkan perbuatan-perbuatan nyata dalam masyarakat berupa tolong-menolong, gotong royong, dan sukaduka dalam kehidupan bermasyarakat.

Setiap kelompok kehidupan manusia mempunyai cara-cara tertentu didalam mengatur hubungan yang terjadi antara hidup dan kehidupannya dengan tidak membedakan suatu kehidupan bermasyarakat dalam kelompok yang kecil maupun besar. Aturan-aturan hidup di dalam masyarakat harus diterima oleh anggota masyarakat sebagai suatu pembatasan karena kehidupan yang bebas tanpa batas tidak dikenal di dalam kehidupan bermasyarakat. Setiap anggota masyarakat merasa terikat dalam kehidupan bermasyarakat dan diperlukan adanya pembatasan untuk lancarnya kehidupan bermasyarakat dan terselenggaranya kepentingan anggota masyarakat yang satu dengan yang lainnya. Kesadaran adanya aturan-aturan yang hidup dan mengikat dalam hidup bermasyarakat merupakan syarat agar terciptanya suasana kehidupan yang tertib, aman, dan damai (Tim Penyusun, 1989/1990 : 19-20).

Di dalam masyarakat, seseorang dikatakan memiliki kesehimbagan dalam hidupnya jika melakukan pelanggaran hukum. Suatu perbuatan melangar hukum mengakibatkan keketoran dalam tubuh masyarakat, dan kegoncangan dalam neraca kesehimbangan masyarakat. Bagimanapun kecilnya suatu goncangan, akan membawa kegoncangan pada neraca kesehimbangan dalam masyarakat. Sedikit banyak kegoncangan yang dirasakan sebagai akibat suatu keketoran, mempengaruhi masyarakat seluruhnya (Projodikoro, 2000 :13-14).

Masyarakat Bali selalu berusaha bersikap sehimbang terhadap alam sekitarnya yang dilandasi oleh kesadaran bahwa alam semesta adalah kompleksitas unsur-unsur yang satu dan yang lainnya mempunyai hubungan yang erat dan membentuk sistem kemestaan. Nilai dasar kehidupan adat di Bali adalah nilai kesehimbangan yang terwujud dalam dua unsur, yaitu (1) penyesuaian diri dan berusaha menjalin hubungan dengan elemen-elemen alam dan kehidupan yang mengitari. (2) ingin menciptakan suasana kedamaian dan ketentraman antar sesama makhluk dan alam tempat manusia hidup. Kedua unsur tersebut digunakan sebagai pedoman masyarakat Bali dalam segala kegiatan hidupnya. Nilai-nilai dan azas tersebut dipersepsikan kedalam ajaran filsafati Tri hita karana (Dharmayudha dan Çantika, 1991 : 6). Sebaliknya, Kaler (1983 : 86) menyatakan bahwa secara harfiah kata tri hita karana berasal dari kata tri, hita dan karana. Tri artinya tiga, hita artinya baik, senang, gembira, lestari, sedangkan karana artinya sebab musabab atau sumbernya sebab. Jadi tri hita karana adalah tiga buah unsur yang merupakan sumbernya sebab timbulnya kebaikan. Ketiga unsur tersebut selalu diusahakan agar terciptanya kesehimbangan hubungan antara manusia dengan Tuhan, antara sesama manusia, dan manusia dengan alam. Dalam menjaga ketiga kesehimbangan tersebut dituangkannya dalam awig-awig desa adatnya.

Hidup bahagia merupakan dambaan setiap orang. Dalam mencapai kebahagiaan hidup, manusia hendakya mengupayakan kondisi yang 
diajarkan dalam filosofis hidup tri hita karana. Hidup bahagia bukan berarti hidup bersenangsenang karena dibalik kebahagiaan ada kedukaaan. Hal ini termuat dalam Kitab Bhagavadgita II. 15 sebagai berikut.

Yam hi na vyathayanty ete purusam purusarsabha,

sama dhuka-sukham dhiram so mrtatvaya kalpate,

Artinya :

Orang yang teguh pikirannya adalah orang yang dapat merasakan sama dan sehimbang antara suka dan duka. Orang yang seperti itu patut mendapatkan kehidupan yang kekal abadi (Maswinara, 1997 : 123).

Kebahagiaan dan kesuksesan merupakan realita dari dinamika kehidupan manusia. Mencari kebahagiaan dan keberahsilan paling banyak menyita berbagai potensi manusia di muka bumi ini. Hiruk pikuk kehidupan manusia dalam mencari kebahagiaan dan keberahsilan perlu dijadikan renungan mendalam sebagai upaya mencari kebahagiaan sesuai dengan filosofis tri hita karana. Jika manusia salah melangkah dalam mencarai kebahagiaan dan keberhasilan, kesehimbangan akan terganggu. Krisna dalam kitab Bhagavagita menyatakan bahwa kebahgiaan harus dicapai dengan sikap yang teguh, sama dan sehimbang dalam menerima suka dan duka dalam hidup ini seperti tertera dalam syair suci, yaitu "sukhamdhukam jayate" artinya menanglah menghadapi suka dan duka. Tidak dapat dipungkiri bahwa banyak orang gagal dalam hidupnya karena tidak bisa memelihara kesehimbangan diri, dan lupa dalam menerima keberhasilannya (Wiana, 2007 :28-29).

Terkait dengan menjaga kesehimbangan di Desa adat Tenganan Pegringsingan salah satu di antaranya warganya dilarang melakukan perkawinan eksogami. Menurut Sanjaya bahwa pelangaran atas larangan perkawinan eksogami, diyakini desanya mengalami keletehan karena warganya tidak mentaati awig-awig desa adatnya.
Keletehan tidak hanya berkaitan dengan pawongan, tetapi juga palemahan. Dengan pelanggaran awig-awig juga menyebabkan kesehimbangan desanya tergamggu. Dalam konteks pawongan, hubungan kekerabatan desanya terganggu karena masyarakat Tenganan Pegringsingan tidak mengenal kekerabatan lain kecuali kekerabatan desa. Selama mempelai tidak dikenai sanksi adat berupa pengusiran dari desanya, mempelai akan selalu menjadi bahan pergunjingan karena melanggar adat istiadat yang berlaku di desanya. Tanpa sanksi adat, ketidaksehimbangan akan tetap dirasakan oleh masyarakatnya karena menjadi persoalan adat. Sebaliknya dalam konteks palemahan, perkawinan eksogami diyakini mengotori lingkungan Tenganan Pegringsingan sebagai akibat dari pelanggaran perkawinan eksogami. Dengan demikian, kesehimbangan palemahan agar dapat dipulihkan kembali maka kedua mempelai harus dikeluarkan dari desanya. Tanpa hal ini kesehimbangan di desa ini akan tetap terganggu. Dengan demikian, semua warganya harus tunduk dan mentaati segala aturan yang berlaku di desa pakraman-nya.

\section{Bentuk Sanksi Dalam Perkawinan Eksogami}

\subsection{Sanksi Denda}

Masyarakat Tenganan Pegringsingan sampai saat ini masih menganggap bahwa perkawinan endogami merupakan perkawinan yang idial dan terhormat. Sebaliknya, perkawinan eksogami merupakan perkawinan yang tidak baik dan dilarang. Pelanggaran atas larangan perkawinan tersebut, mempelai dan orang tuanya sama-sama dikenakan sanksi adat.

Bagi umat Hindu di Bali, istilah "sanksi adat" lebih populer dengan sebutan "pamidanda". Windia (2003 : 29) menyatakan ada tiga jenis pamidanda, yaitu arta denda, sangaskara danda, dan jiwa danda. Artadanda adalah denda dalam wujud materi berupa berbagai benda yang mempunyai nilai ekonomi atau berupa uang. Uang yang 
dimaksud berupa uang kertas atau uang kepeng. Sebaliknya, pembayaran denda sama sekali belum pernah dilakukan dengan menggunakan cek atau kartu kredit. Dalam danda arta juga dilakukan dengan ayahan panukun kasisipan, yaitu kewajiban untuk melakukan perbuatan tertentu (ngayah) selama waktu tertentu sebagai pengganti atas kewajiban membayar danda materi atau uang. Sangaskara danda adalah sanksi denda berupa melaksanakan upacara tertentu. Denda ini dikenakan kepada warganya yang melakukan perbuatan tertentu yang dianggap menimbulkan leteh (suatu keadaan yang dianggap suci) seperti pencurian, pembunuhan, dan berbagai tindakan pidana yang lainnya. Perbuatannya tersebut tidak hanya dianggap merugikan secara material tetapi juga menimbulkan ketidaksehimbangan bathin. Pelaksanaan sangaskara danda berupa upacara prayascita atau upacara pecaruan. Danda sangaskara juga biasanya dibebankan terhadap perbuatan yang dianggap dapat menimbulkan perasaan tidak menyenangkan seperti mengeluarkan kata-kata kotor, mencaci maki dan sebagainya. Jiwa danda atau atma danda adalah sanksi yang berkaitan dengan jiwa dari pelaku yang melakukan pelanggaran. Pada zaman dahulu hukuman ini dilakukan dengan tikaman sebilah keris atau menenggelamkan ke laut bagi yang melanggar. Akan tetapi dewasa ini jiwa danda dapat berupa pengaksama (menyampaikan permintaan maaf) dihadapan paruman (rapat) desa.

Sebaliknya, Dharmayuda (2001 : 34-37) mengklasifikasi jenis pamidanda menjadi lima macam, yaitu (1) denda arta, ((2) ayahan penukun kesisipan, (3) rerampagan, (4) kedaut karang ayah, (5) penyangaskara, (6) kasepekang, dan kanoroyang. Di antara berbagai jenis sanksi adat tersebut, sanksi adat pada perkawinan eksogami di Tenganan Pegringsingan adalah sanksi denda arta dan sanksi kanoroyang. Sanksi denda arta jumlah nominalnya sudah ditetapkan pada paos 7 awigawig Desa Adat Tenganan Pegringsingan sebagai berikut :

Mwah tingkah $i$ wong desa ika sinalih tunggal ngasampingang piyanak nyane, wiyadin nyama luh, mwah nyolongang kacolongan, pada tan kawasa, tka wnang kadanda olih desa, gung arta 75.000 mantuk ka desa saungkul.

Terjemahannya :

Dan prihal salah seorang warga desanya membiarkan anaknya kawin keluar desa baik anaknya perempuan maupun saudara wanitanya atau ikut membantu/memberi kesempatan, sama sekali dilarang, serta didenda oleh desa sebesar 75.000, semuanya diserahkan kepada desa (Desa Adat Tenganan, tt : 90).

Kutipan di atas menunjukkan bahwa sanksi denda yang harus dibayarkan oleh orang tua mempelai berupa uang kepeng asli sebanyak 75.000 uang kepeng asli. Dewasa ini di Bali uang kepeng asli per keteng (biji) harganya Rp. 3000 (tiga ribu rupiah). Dengan demikian, denda arta yang mesti dibayar oleh orang tua mempelai Rp. 225000000 (dua ratus dua puluh lima juta rupiah).

Seiring dengan perkembangan zaman, Timur menyatakan bahwa sanksi denda arta atas pelanggaran larangan perkawinan eksogami sudah mengalami perubahan. Artinya, warganya yang melanggar larangan perkawinan eksogami tidak lagi membayar Rp.225 000 000, tetapi Rp.18000 000 (delapan belas ribu rupiah). Hal ini dilakukan dengan pertimbangan kemanusiaan, yaitu meringankan beban keluarga mempelai. Di samping itu juga memepali sudah kehilangan semua haknya di Desa Pakraman Tenganan Pegringsingan. Orang tua memepelai juga tiap bulan wajib membayar uang Rp.1000 (seribu rupiah) kepada desa adatnya sebagai bagai tanda kesalahan pelanggaran atas larangan perkawinan eksogami. Walaupun dendanya sudah dirubah, tetapi orang tua mempelai selama hidupnya 
akan selalu dihantui oeh perasaan bersalah atas perbuatan anaknya yang melanggar melakukan perkawinan eksogami.

\subsection{Sanksi Moral}

Setiap gangguan atau benturan terhadap kesehimbangan kehidupan orang perorangan atau orang-orang banyak sebagai satu kesatuan dalam ketertiban hukum dianggap sebagai suatu pelanggaran (delik) adat (Ter Haar, 2001 : 226). Delik adat adalah semua perbuatan atau kejadian yang bertentangan dengan kerukunan, ketertiban, keamanan, rasakeadilan, dankesadaran masyarakat bersangkutan baik sebagai akibat dari perbuatan yang dilakukan oleh seseorang, sekolompok orang maupun pengurus adat sendiri. Perbuatan yang melanggar adat dipadang dapat menimbulkan kegoncangan sehingga tergganggunya kesehimbangan kosmos. Kegoncangan dapat menimbulkan reaksi masyarakat berupa sanksi adat (Widnyana, $1993: 6$ ).

Lesqiller dalam disertasinya "Het Adat Delectenrechtinde Magische Wereldbeschouwing" sebagaimana dikutip oleh Soeroyo Wignjodipoero menjelaskan bahwa sanksi adat sangat diperlukan untuk mengembalikan ketentraman magis yang diganggu, dan meniadakan atau menetralisir suatu keadaan sial yang ditimbulkan oleh suatu pelanggaran adat (Tim Penyusun, 2010 : 76-77). Sebaliknya, Sianturi (1986 : 30) menyatakan bahwa sanksi adat memiliki beberapa fungsi, yaitu (1) sebagai alat pemaksa agar seseorang atau warga mentaati norma-norma yang berlaku, (2) sebagai norma hukum untuk ditaati, dan (3) sebagai akibat hukum bagi seorang yang melanggar norma hukum. Senada dengan pendapat Sianturi, Çantika mengemukakan bahwa sanksi adat dapat digunakan untuk memulihkan kepada keadaan trepti (tertib), dan sukerta (tentram) yakni adanya kesehimbangan dari sattyam (kebenaran), siwam (kesusilaan), dan sundaram (kebahagiaan) yang terjawantah ke dalam filosofis tri hita karana (tiga penyebab kebahagiaan) (Tim Penyusun, 2010 : 94-95).
Sanksi adat yang dijatuhkan atas pelanggaran larangan perkawinan eksogami di Desa Adat Tenganan Pegringsingan tidak hanya berupa sanksi denda, tetapi juga sanksi moral. Sanksi moral adalah sanksi batin berupa rasa malu atau rasa bersalah (berdosa) (All-Barry, 2001: 292). Covarrubias ( 2013 :69) mengemkakan bahwa Di Bali sanksi moral membawa beban jauh lebih besar dibandingkan dengan hukuman badan, kesalahan-kesalahan ringan mengakibatkan denda, dan penyitaan harta benda, atau penundaan sementara dari masyarakat. Akan tetapi hukuman bagi kesalahan-kesalahan besar bervariasi antara boikot yang menakutkan dari semua kegiatan desa sampai pengucilan tetap, pengusiran sepenuhnya dari desa. Seorang yang disingkirkan dari desanya tidak diijinkan masuk ke munitas lain. Dia benarbenar menjadi kasta terbuang sebagai sebuah hukuman yang jauh lebih berat dari kematian fisik bagi pikiran orang Bali karena seseorang secara terbuka dipermalukan, membunuh dirinya sendiri.

Dharmayuda (2001 : 34-37) mengklasifikasikan sanksi adat di Bali menjadi lima macam, yaitu (1) denda arta, (2) ayahan penukun kesisipan, (3) rerampagan, (4) kedaut karang ayah, (5) penyangaskara, (6) kasepekang dan kanoroyang. Di antara sanksi tersebut, sanksi kanoroyang merupakan sanksi moral yang paling berat pada perkawinan eksogami di Desa Tenganan Pegringsingan. Warganya yang dikenakan sanksi adat kasepekang saja sudah diangap berat apalagi sanksi kanoroyang. Krama adat yang dijatuhi sanksi kasepekang, statusnya masih tetap diakui sebagai krama adat, tetapi ia ditempatkan di luar tata hukum. Maksudnya, krama yang bersangkutan tidak dikenakan aturan hukum adat seperti tidak mendapatkan pemberitahuan (tan polih araharahan), tidak mendapat layanan kentongan (tan polih pasuwaran kulkul), dan tidak mendapat bantuan banjar. Ia juga masih dapat menggunakan kuburan, tetapi tidak mendapatkan bantuan layanan banjar atau desa pakraman. Sebaliknya, dalam sanksi adat kanoroyang, status yang bersangkutan 
sudah tidak lagi sebagai warga desa pakraman karena tidak hanya dikucilkan, tetapi juga diusir dari desanya. Wayan Koti Çantika membedakan antara sanksi adat kasepekang dan kanoroyang. Dalam sanksi adat kasepekang, seseorang yang dikenai sanksi masih diakui keberadaannya sebagai krama, tetapi dikucilkan dari berbagai aktivitas banjar/desa pakraman. Sebaliknya, dalam sanksi adat kanoroyang, seseorang tidak saja dikucilkan, tetapi juga dianggap tidak ada (Windia, 2008 : 50-51).

Pelangaran atas larangan perkawinan eksogami di Tenganan Pegringsingan akibatnya tidak hanya dirasakan oleh mempelai, tetapi juga orang tuanya sendiri. Orang tua mempelai harus membayar sejumlah uang, sedangkan sanksi untuk anaknya yang melakukan perkawinan eksogami tidak hanya diusir, tetapi juga kehilngan semua hak-haknya di desa adat tersebut. Sanksi adat ini diputuskan melalui sangkepan (rapat) desa adat yang dihadiri oleh seluruh krama desa adat. Penjatuhan sanksi juga diputuskan secara terbuka dalam forum sangkepan desa adat. Di dalam sistem pengambilan keputusan tersebut menimbulkan rasa malu dan rasa berdosa dari pihak keluarga mempelai karena anaknya berperilaku tidak sesuai dengan nilai-nilai, norma-norma dan aturanaturan yang berlaku di masyarakatnya terutama berkaitan dengan perkawinan eksogami. Dengan penjatuhan sanksi, mempelai sama sekali tidak memiliki hak termasuk hak untuk tinggal di desa adatnya sendiri.

\section{Implikasi Sanksi Adat terhadap Perkawinan Eksogami}

\subsection{Ketidakemansipasian}

Secara fungsional, adat yang diciptakan dalam suatu sistem sosial masyarakat dimaksudkan agar terjadi suatu order (tertib) sosial di masyarakat. Menurut Comte dan Spencer, masyarakat dipandang sebagai sistem sosial yang terdiri atas bagian-bagian yang saling tergantung satu sama lain (Poloma, 1992 : 25). Oleh karena itu, lembaga adat sebagai salah satu struktur yang ada dalam masyarakat diharapkan dapat memberikan rasa aman dan nyaman sehingga dapat tercipta kehidupan masyarakat yang harmonis.

Masyarakat Bali terorganisir dalam organisasi tradisional, yaitu desa adat atau desa pakraman. Surpha (2002, 16-17) menyatakan bahwa desa pakraman merupakan institusi yang berfungsi memelihara dan menegakkan adat istiadat yang berlaku pada tiap-tiap desa pakraman. Jika terjadi pengingkaranpengingkaran adat, dipandang sebagai suatu hal yang tercela dan merusak kerukunan hidup krama desa. Sebaliknya, untuk mencegah pengingkaranpengingkaran ini, desa pakraman bertugas menata dan mengatur kehidupan paguyuban warga desanya dalam hubungan dengan pawongan, palemahan, dan parahyangan. Pitana (Budiana, 2004 : 221) menyatakan bahwa desa pakraman harus mampu menjadi wahana pengembangan berbagai nilai positif yang ada pada kebudayaan Bali, seperti nilai demokrasi, toleransi, adaptasi, kreativitas, fleksibilitas, serta sebagai wahana eliminasi berbagai tradisi yang tidak sesuai dengan perkembangan zaman. Desa adat (desa pakraman) sebagai institusi yang mengatur tatakrama masyarakat Bali harus mampu memilah dan memilih tradisi yang perlu dikembangkan dan tradisi yang ditinggalkan. Akan tetapi dewasa ini tradisi di Bali yang masih menunjukkan ketidakemasipasiannya salah satu di antaranya adalah perkawinan antarwangsa. Hobart (1980 : 109-110) menyatakan bahwa sejumlah individu yang melakukan perkawinan antawangsa masih memperlihatkan ketidakemansipasian karena mendapat perlakuan diskriminatif pada saat ritual perkawinan. Mempelai perempuan yang wangsanya lebih rendah (sudra wangsa) pada saat ritual perkawinan bukan langsung bersanding dengan mempelai laki-laki triwangsa, tetapi dengan sebilah keris milik memepelai laki-laki atau digantikan dengan tiang rumah (adegan) yang sudah dihias dengan pakaian pengantin laki-laki. 
Sudarma (2012 : 261 ) dalam disertasinya berjudul "Perkawinan Nyeburin di Tengah Perubahan Sosial di Kabupaten Tabanan" menyatakan bahwa ketidakemasipasian perkawinan antarwangsa terutama pada perkawinan nyeburin bahwa kedua mempelai dan keluarganya dikeluarkan dari kerabatnya, dan dilarang sembahyang di tempat suci milik keluarga besarnya. Sanksi keluarga tersebut dewasa ini tergolong berat karena bertentangan dengan nilai-nilai kemanusiaan.

Perkawinan eksogami di Desa adat Tenganan Pegringsingan sampai saat ini masih menunjukkan ketidakemansipasian dalam perkawinan. Ketidakemansipasiannya tampak pada penerapan sanksi adat bagi warganya yang melakukan perkawinan eksogami. Walaupun sanksi adat pada perkawinan eksogami bertentangan dengan ajaran agama, dan nilai-nilai kemanusiaan, tetapi warganya takut melawan norma-norma dan nilainilai budaya masyarakatnya. Dengan demikian, warganya selalu dihadapkan pada masalah yang sulit jika melakukan perkawinan eksogami.

Sanksi perkawinan antarwangsa hampir sama dengan perkawinan antarwarga berbeda adat di Desa Adat Tenganan Pegringsingan. Perkawinan antarwangsa dan perkawinan eksogami di desa ini sama-sama diberikan sanksi. Akan tetapi sanksi perkawinan antarwangsa jauh lebih ringan dari perkawinan eksogami. Jika perkawinan antarwangsa biasanya sanksinya berupa pengucilnya mempelai dan orang tuanya dari keluarganya sendiri, tetapi masih memiliki hak sebagai warga masyarakat dan untuk tinggal di desanya. Sebaliknya, perkawinan antarwarga yang berbeda adat di Desa Adat Tenganan Pegringsingan mengakibatkan semua hak-haknya dicabut. I Nengah Timur menyatakan bahwa pencabutan semua hak-haknya, mempelai sama sekali tidak memiliki hak lagi di desanya. Penjatuhan sanksi dalam perkawinan eksogami penting dilakukan untuk menjaga dan mempertahankan tradisi perkawinan endogamy di desanya. Tanpa sanksi, warga masyarakatnya akan mengabaikan larangan pada perkawinan eksogami. Senada dengan pendapat I Nengah Timur, Putra (2015 : 324325) mengemukakan bahwa pemberian sanksi dimaksudkan untuk mengembalikan kesucian dan kesehimbangan desa dari keletehan (keadaan tidak suci).

Penerapan sanksi adat pada perkawinan eksogami di Tenganan Pegringsingan telah menunjukkan ketidakemansipasian dalam perkawinan. Warganya yang melakukan perkawinan eksogami tidak mendapatkan perlindungan bahkan semua hak-haknya dicabut oleh desanya. Wertheim (Wisnumurti, 2010 : 369) mengatakan bahwa emansipasi berkaitan dengan pembebasan manusia dari alam sekeliling, kebebasan potensi-potensi kreatif manusia dari struktur-struktur masyarakat yang mencekik teristimewa dari kemusnahan. Pembebasan manusia juga dari bentuk-bentuk penguasaan dan perbudakan yang membelenggu yang diciptakan oleh manusia sendiri. Penerapan sanksi adat dalam perkawinan eksogami di Tenganan Pegringsingan juga bertentangan dengan Undang-undang Republik Indonesia No.39 Tahun1999 tentang Hak-hak Asasi Manusia yang termuat pada pasal 3 ayat 3 , dan pasal 4 sebagai berikut.

Pasal 3 ayat 3 memuat bahwa setiap orang berhak atas perlindungan hak asasi manusia dan kebebasan dasar manusia tanpa diskriminasi.

Pasal 4 memuat bahwa setiap orang memiliki hak untuk hidup, hak untuk tidak disiksa, hak untuk kebebasan pribadi, pikiran dan hati nurani, hak beragama, hak untuk tidak diperbudak, hak untuk diakui secara pribadi dan persamaan dihadapan hukum adalah hak asasi manusia yang tidak dapat dikurangi dalam keadaan apa pun dan oleh si apapun (Anonim, $2016: 4-5$ ).

Kutipan di atas menunjukkan bahwa perkawinan antarwarga berbeda adat di Tenganan Pegringsingan mencerminkan ketidakemansipasian. Pelanggaran atas 
perkawinan eksogami, semua hak-haknya dicabut oleh desanya. Dengan pencabutan hakhaknya, mereka sama sekali tidak memiliki hak termasuk hak untuk tinggal di Desa Pakraman Pegringsingan.

\subsection{Tidak Memperoleh Kesejahteraan}

Pelanggaran atas larangan perkawinan eksogami, kedua mempelai tidak memperoleh kesejahteraan dari desa adatnya. Setiap manusia memiliki berbagai kebutuhan hidup, lebih-lebih sudah melakukan perkawinan. Menurut ajaran agama Hindu perkawinan adalah sebuah yadnya (korban suci). Perkawinan sebagai awal untuk menuju masa grehasta merupakan masa yang paling penting dalam kehidupan manusia. Setiap orang yang akan melaksanakan perkawinan harus menyadari arti dan hakikatnya. Di dalam grehasta, ada tiga perilaku yang harus dilaksanakan, yaitu dharma, artha, dan kama. Dharma adalah aturanaturan yang berkaitan dengan dharma agama dan negara. Artha adalah kebutuhan hidup berumah tangga untuk mendapatkan kesejahteraan berupa materi dan pengetahuan dan kama yaitu rasa kenikmatan yang diperoleh dalam keluarga sesuai dengan ajaran agama (Artayasa, dkk, 1998 : 4--5) .

Dalam kitab Manawa Dharma Sastra dimuat bahwa perkawinan memiliki tiga tujuan, yaitu (1) dharma sampati (bersama-sama suami istri mewujudkan pelaksanaan dharma), (2) praja (melahirkan keturunan), dan (3) rati (menikmati kehidupan seksual dan kepuasan lainnya). Dari ketiga tujuan perkawinan tersebut, praja menempati kedudukan yang penting dalam keluarga karena dengan melahirkan putra-putri yang suputra dapat menyelamatkan para leluhur dari neraka. Keluarga yang dikaruniai keturunan yang baik akan membawa leluhurnya pada kondisi yang lebih baik, yaitu leluhurnya akan dapat mencapai surga atau moksa (Suja, 1999 : 4-57).

Perkawinan dilaksanakan tidak hanya sekadar hubungan biologis, tetapi identik dengan yadnya samkara, yaitu perkawinan dan segala akibatnya bernilai suci terutama membersihkan atau menyucikan sukla swanita (bibit) kedua mempelai. Perkawinan juga menyangkut jasmani/ lahiriah, dan batin/rohaniah. Ikatan lahir batin bermakna kemanunggalan antara sekala (di dunia nyata) dan niskala (di dunia tidak nyata). Tuhan memanfaatkan perkawinan untuk menciptakan manusia dalam kitab Bhagawadgita III. 10 dinyatakan sebagai berikut.

"Sahajńah prajah srița pura ẃaca prājapatih

Anena prasawisya dhiwam esa ẃa stiwisista kāmaduk"

Terjemahannya :

Sesungguhnya sejak dahulu dikatakan bahwa Tuhan telah menciptakan manusia melalui yadnya dengan (cara) ini engkau akan berkembang, sebagai lembu perahan yang memerah susunya karena keinginanmu sendiri (Pudja, 1985 : 76).

Kutipan di atas menunjukkan bahwa Tuhan telah menciptakan manusia agar berkembang. Manusia bisa berkembang hanya melalui perkawinan.

Wiana (2006 : 45) menyatakan bahwa sesorang bisa dikatakan hidup sejahtera jika kebutuhan hidupnya terpenuhi. Kebutuhan yang dimaksud, yaitu (1) kebutuhan biologis adalah kebutuhan akan sandang, pangan, papan, dan kesehatan. (2) kebutuhan sosial adalah kebutuhan untuk dapat menerima dan diterima dalam pergaulan hidup di masyarakat, dan (3) kebutuhan filosofis adalah kebutuhan akan pendidikan dan kebudayaan di dalamnya termasuk hidup beragama. Salah satu di antara ketiga kebutuhan tersebut, kebutuhan akan sandang, pangan, papan, dan kesehatan sangat diperlukan oleh masyarakat Tenganan Pegringsingan. Kebutuhan tersebut akan bisa di raih dari desanya jika warganya melakukan perkawinan endogamy sesama warga desanya sendiri. Sebaliknya, kesejahteraan mempelai praktis hilang jika warganya melakukan perkawinan eksogami. Dengan demikian, kedua 
memepelai harus berhati-hati dalam melakukan perkawinan jika masih ingin tetap memperoleh kesejahteraan dari desanya.

Desa Tenganan Pegringsingan merupakan sebuah desa kuno di Bali yang masih kental dengan tradisi perkawinan endogamy desa. Jika kedua mempelai ingin memperoleh kesejahteraan dari desa adatnya, warganya harus melakukan perkawinan endogamy. Tanpa perkawinan ini praktis kesejahteraan mempelai hilang walaupun perkawinan bernilai sacral dan memiliki tujuan yang mulia, dilakukan sama-sama saling mencintai, dan tidak melanggar undang-undang perkawinan di Indonesia. Kesejahteraan dalam perkawinan di Desa Adat Tengan Pegringsingan hanya bisa diperoleh melalui perkawinan endogami sesama warga adatnya sendiri. Kesejahteraan berasal dari kata "sejahtera" artinya aman santosa dan makmur, selamat (terlepas dari segala macam gangguan), kesukaran dan sebagainya). Kata "sejahtera" mendapat nasalisasi "ke" dan akhiran "an" sehingga menjadi kesejahteraan artinya keamanan, keselamatan, ketentraman, kesenangan hidup, dan kemakmuran (Tim Penyusun, 1993 :794).

Timur sebagai warga Tenganan Pegringsingan menyatakan bahwa perkawinan sangat menentukan mempelai bisa tidaknya memperoleh kesejahteraan dari desanya. Ketentuan mendapatkan kesejahteraan dari desanya jika warganya melakukan perkawinan endogamy. Kesejahteraan mempelai tidak hanya berupa beras, tetapi juga uang yang diperoleh dari aset-aset milik desa seperti hasil subak, pendapatan dari pariwisata, hasil sawah, dan hasil kebun. Pembagian kesejahteraan dilakukan secara rutinitas perbulan, dan secara insidental pada saat upacara Ngusabha Sambah. Kesejahteran yang diberikan disesuaikan dengan jabatan pada struktur sosial, yaitu Luwanan mendapat bagian beras $100 \mathrm{~kg} /$ bulan, dan uang Rp 2.000.000 (dua juta rupiah)/bulan, sedangkan pada saat Usabha Sambah mendapat bagian beras $300 \mathrm{~kg}$, dan uang sebesar Rp 3.000.000 (tiga juta rupiah); Bahan Roras (Bahan Duluan/Keliang Desa dan Bahan Tebenan) masing-masing mendapat bagian beras $100 \mathrm{~kg} / \mathrm{bulan}$, dan beras $250 \mathrm{~kg}$ serta uang Rp. 2,500.000,-(dua juta lima ratus ribu rupiah) pada saat upacara Ngusabha Sambah; Tambalapu Roras, mendapat bagian beras $100 \mathrm{~kg} / \mathrm{bulan}$, dan saat ritual Usabha Sambah mendapat bagian beras $250 \mathrm{~kg}$, dan uang Rp 2,500.000,- (dua juta lima ratus ribu rupiah); Pengeluduan, mendapat bagian beras $100 \mathrm{~kg} / \mathrm{bulan}$, dan beras $300 \mathrm{~kg}$ serta uang Rp 3.000.000,- (tiga juta rupiah) ketika ritual Ngusabha Sambah. Dengan ketentuan tersebut, mempelai harus hati-hati melaksanakan perkawinan karena berhak tidaknya mempelai memperoleh kesejahteraan dari desa adatnya.

\subsection{Kehilangan Atas Semua Hak-haknya}

Manusia dalam kehidupan bermasyarakat mempunyai cara-cara tetentu mengatur hubungan antara hidup dan kehidupan. Hubungan tersebut diperlukan aturan-aturan yang didasarkan atas nilai-nilai mengenai apa yang dianggap baik atau tidak patut. Aturan-aturan itu merupakan patokan mengenai apa yang boleh diperbuat sehingga aturan-aturan itu membatasi sikap, tingkah laku dan perbuatan manusia yang satu dengan manusia yang lainnya. Aturan-aturan kemasyarakatan yang hidup dan berkembang dan diterima sebagai suatu keharusan karena mereka menganggap pentingnya ada suatu pembatasan. Kehidupan yang bebas tanpa batas tidak dikenal di dalam kehidupan bermasyarakat. Dengan demikian, setiap masyarakat merasa terikat dalam suatu kehidupan bermasyarakat serta mereka sangat memerlukan adanya pembatasan guna terciptanya kehidupan yang tertib, aman dan damai (Majelis Pembina Desa Adat Daerah Tk.I Bali, 1992/1993 : 19).

Di Bali terdapat dua organisasi desa yang berbeda secara substansial dan fungsional, yaitu desa adat dan desa dinas. Masing-masing desa ini mempunyai struktur dan fungsi sendiri 
sehingga keterikatan anggota masyarakat kepada kedua organisasi ini berbeda. Raka (2002 :19) menyatakan bahwa desa adat adalah suatu kesatuan wilayah yang warganya secara bersamasama mengkonsepsikan dan mengaktifkan upacara keagamaan untuk memelihara kesucian desa. Rasa kesatuan sebagai warga desa adat terikat karena adanya karang desa (wilayah territorial), awig-awig desa adat (sistem aturan desa dengan peraturan pelaksanaannya), dan Pura Khayangan Tiga (tiga pura di desa sebagai system tempat persembahyangan bagi warga desa adat).

Kehidupan sosial budaya masyarakat Bali teroganisasi dalam oragnisasi sosial yang disebut dengan desa adat atau desa pakraman. Desa adat pada zaman Bali kuno disebut banwa atau banua (Goris, 1954 : 59). Covarrubias (1986 : 56) mengemukakan bahwa desa adat merupakan kesatuan wilayah tertutup atau terbatas pada pemujaan leluhur dan peraturan administrasi masyarakat. Masing-masing desa adat dilengkapi dengan unsur-unsur kesatuan pura (tempat suci) sebagai pengikat sebuah desa, yaitu Khayangan Tiga (Pura Desa, Pura Puseh, Pura Dalem). Senada dengan Covarrubias, Suputra menyatakan bahwa desa adat mencakup dua hal, yaitu desa adat sebagai wadah, dan adat istiadat sebagai isi dari wadah. Desa adat sebagai lembaga tradisional mewadahi kegiatan sosial, budaya dan keagamaan masyarakat Hindu di Bali, sedangkan adat istiadat adalah tatakrama kehidupan masyarakat umat Hindu di Bali yang telah menjadi tradisi kemasyarakatan sebagai warisan budaya bangsa (Wisnumurti, 2010:175-176).

Setiap desa pakraman (desa adat) di Bali termasuk desa adat Tenganan Pegringsingan memiliki aturan tertulis maupun tidak tertulis yang disebut dengan awig-awig desa adat. Awigawig desa ini merupakan peraturan atau ketentuan dasar yang dibuat oleh krama (warga) desa adat yang dijadikan pedoman perilaku mereka. Awigawig juga mengarahkan dan mengatur pola- pola perilaku krama desa adat untuk mencapai ketertiban dan kehidupan bermasyarakat, dan menjadi pedoman menyelesaikan sengketa di antara sesama krama desa adat maupun krama desa adat dengan desa adat. Di samping itu, awigawig desa adat merupakan penjabaran kongkrit dari Tri Hita Karana yang mengatur empat hal utama, yaitu (1) tata sukerta parahyangan merupakan aturan dan ketentuan yang menjadi dasar atau pedoman perilaku hubungan krama desa adat dengan Hyang Widi (Tuhan). (2) Tata sukerta pawongan merupakan aturan dan ketentuan yang menjadi dasar atau pedoman perilaku hubungan antara sesama krama desa adat baik hubungan vertical maupun horizontal dalam kehidupan bermasyarakat. (3) tata sukerta palemahan merupakan aturan dan ketentuan yang menjadi dasar atau pedoman perilaku hubungan krama desa adat dengan alam sekitarnya, dan (4) sanksi bagi krama adat yang melanggar awig-awig dengan pasuarannya (peraturan pelaksanaan) (Gorda, 1999 : 10-11).

Awig-awig dalam bahasa Bali berasal dari kata "wig". Kata "wig" lazim disebut dengan istilah "uig" artinya terlalu memilih, suka mengganggu. Nguig artinya suka mengganggu. Da demen nguig timpal artinya jangan senang mengganggu teman (Tim Penyusun, 2008 :776). Kata “wig” kemudian mendapat nasalisasi "a" sehingga menjadi awig yang artinya tidak rusak. Astiti (2005 :19) meyatakan bahwa awig-awig adalah patokanpatokan tingkah laku baik tertulis maupun tidak tertulis yang dibuat oleh masyarakat bersangkutan berdasarkan keadilan dan kepatutan yang hidup dalam masyarakat dalam hubungan antara krama (waraga) desa dengan Tuhan, antar sesama krama maupun antara krama dengan lingkungannya.

Awig-awig desa adat disusun oleh krama adat melalui sangkepan (rapat) desa adat. Awig-awig yang telah ditetapkan oleh sangkepan desa adat, sebelum diberlakukan kepada seluruh masyarakat, terlebih dahulu dilakukan upacara pengesahan secara adat keagamaan yang disebut Upacara 
Pasupati. Upacara ini diselenggarakan pada salah satu Pura Tri Khayangan Tiga milik desa adat yang bersangkutan. Upacara pengesahannya dihadiri oleh seluruh masyarakat adat dan disaksikan oleh aparatur Pemerintah daerah. Upacara pasupati bermakna memberikan kekuatan sacral dan kekuatan frofan terhadap awig-awig desa adat. Dengan demikian, awig-awig desa adat di Bali tidak hanya memiliki kekuatan berupa ganjaranganjaran dan hukuman-hukuman yang bersifat duniawi dan manusiawi (frofan), tetapi juga memiliki ganjaran dan hukuman yang beresifat supra manusiawi dan sorgawi (sakral).

Surpha (2002 : 56-57) mengemukakan bahwa tiap-tiap anggota desa adat memiliki berbagai kewajiban dan hak. Kewjiban-kewajiban yang dimaksud meliputi (1) wajib melaksanakan ayahan desa (tugas krama desa) berupa kerja bakti memperbaiki/membangun pura milik desa adat, melaksanakan upacara dewayajña, menyelenggarakan upacara bhutayajña setiap Tilem Kesanga, melaksanakan upacara makiyis, melaksnakan pembangunan untuk desa adat, dan lain sebgainya. (2) wajib mentaati aturan-aturan yang berlaku di desa adatnya. (3) wajib menjaga keamanan dan ketentraman bersama. (4) menjaga nama baik desanya dan melaksanakan suka-duka (gotong royong) antara sesamanya. Sebaliknya, hak-haknya, yaitu berhak mengeluarkan pendapat dalam sangkepan (rapat), berhak menggunakan fasilitas milik desa pakraman, berhak minta bantuan untuk menyelenggarakan upacara agama, dan berhak mendapat bantuan dalam keadaan bahaya dan sebagainya. Dengan adanya sejumlah hak dan kewajiban memungkinkan krama desa saling mendukung dalam mengaktipkan suatu kegiatan di desa adatnya.

Jika di antara krama (anggota) desa pakraman menyimpang dari berbagai kewajiban yang tertera pada awig-awig desa adatnya, dia akan dijatuhi sanksi adat. Tanpa sanksi, awigawig tidak memiliki wibawa untuk ditaati oleh masyarakat. Van Vollenhoven merumuskan hukum adat sebagai peraturan adat istiadat yang ada sanksinya dan mengandung paksaan. Soepomo, ter Haar, Lesquiller (Dharmayuda, 2001 : 36-37) mengatakan bahwa sanksi adat adalah bentuk tindakan atau usaha-usaha untuk mengembalikan keseimbangan termasuk keseimbangan magis akibat adanya gangguan pelanggaran adat.

Dikalangan penelitibaratmenganggap hukum adat itu bersifat unik dan khas. Sifat uniknya tampak pada pembauran antara gejala hukum kasat mata dengan alam hukum suprarnatural (gaib). Dengan demikian, F.D Hollemen memandang corak utama hukum adat adalah "magisch religieus" artinya hukum adat selalu berhubungan dengan unsurunsur keagamaan penduduk serta kepercayaan yang sakral. Sebaliknya, sifat khasnya terpancar dari alam pikiran yang menjadi dasar substansi norma hukum adat yang dilandasi oleh pikiran berpartisipasi. Artinya, apapun di dunia ini adalah saling kait mengait. Dengan demikian, setiap orang harus mengusahakan hubungan harmonis dengan berbagai unsur di luar dirinya. Manusia harus selalu hidup rukun dengan sesama, dengan lingkungan alamnya untuk menciptakan kesehimbangan melalui saling memberi dan menerima (Dharmayuda, 2001 : 55).

Desa Tenganan Pegringsingan, Karangasem Bali sampai saat ini masih menerapkan larangan pada perkawinan eksogami, berpoligami, dan perceraian. Sebaliknya, perkawinan yang dianjurkan dan diharapkan adalah endogami desa yang terjadi sesama warga adatnya sendiri. Perkawinan endogami akan menentukan statusnya sebagai krama desa yakni warga yang memiliki hak untuk mengikuti sangkep (rapat) di Bale Agung. Rapat dilakukan untuk mengambil keputusankeputusan di desa adat, sedangkan jika perkawinan dilakukan secara eksogami, haknya praktis hilang. Hak untuk mengikuti sangkepan sangat istimewa karena dapat menentukan keputusan-keputusan yang menentukan perkembangan desa dan mendapat bagian dari hasil perolehan aset-aset desa (Sujaya, 2007 : 39-40). 
Putu Yudiana meyatakan bahwa masyarakat Desa Tenganan Pegringsingan memiliki tiga macam krama, yaitu krama desa, krama gumi pulangan, dan krama gumi. Krama desa adalah anggota masyarakat yang paling istimewa dari pada anggota masyarakat yang lainnya. Keistimewaannya ditunjukkan bahwa hanya mereka yang berhak duduk dalam struktur sosial, ikutdalam sangkepan, mendapat bantuan kesehatan dan pembagian hasil dari aset-aset desa. Krama gumi pulangan adalah krama yang tidak memiliki hak-hak istimewa lagi. Jika anaknya menikah, praktis hak istimewanya digantikan oleh anaknya yang baru menikah. Denagan pengambilalihan hak istimewanya, hak sebagai krama desa hilang. Sebaliknya, krama gumi adalah krama yang telah menjadi duda atau janda. Krama ini tidak berhak ikut dalam struktur sosial, dan ikut dalam sangkepan. Akan tetapi krama gumi pulangan masih bisa mendapatkan kesejahteraan atas dasar kebijakan dari desanya, sedangkan krama gumi, sama sekali tidak memperoleh pembagian yang bersumber dari kekayaan desa. Maksudnya, mereka hanya menikmati harta warisan dan hasil usahanya sendiri.

Struktur sosial Desa Adat Tenganan Pegringsingan terdiri atas Luwanan, Bahan Roras, Tambalapu Roras, dan Pengeluduan. Luwanan, adalah jabatan yang teratas yang anggotanya terdiri atas enam pasang yang bertugas sebagai penasihat dalam pemerintahan. Bahan Duluan/Bahan Roras adalah jabatan yang bertugas sebagai pengambil keputusan dalam pemerintahan. Keliang Desa adalah jabatan untuk melaksanakan pemerintahan desa sehari-hari. Tambalapu Roras, yaitu jabatan yang bertugas menyampaikan perintah keliang desa. Sebaliknya, pengeluduan adalah jabatan khusus sebagai membantu keliang desa dalam mencari perlengkapan sarana upacara keagamaan. Struktur sosial krama desa di Desa Pakraman Tenganan Pegringsingan sebagai berikut.
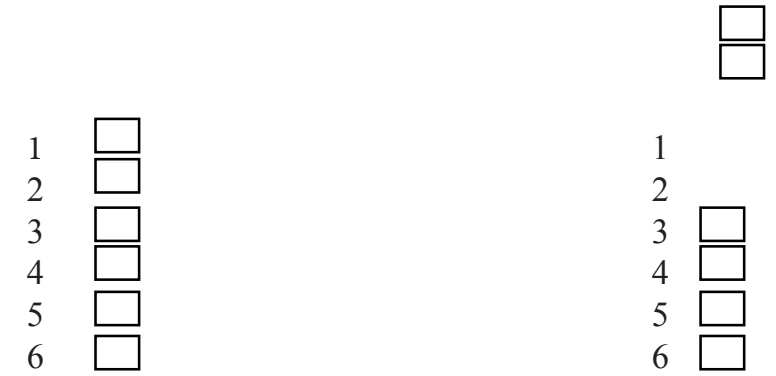

1

2

3

4

5

6

Bahan Tebenan

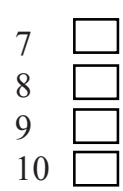

Tambalapuroras
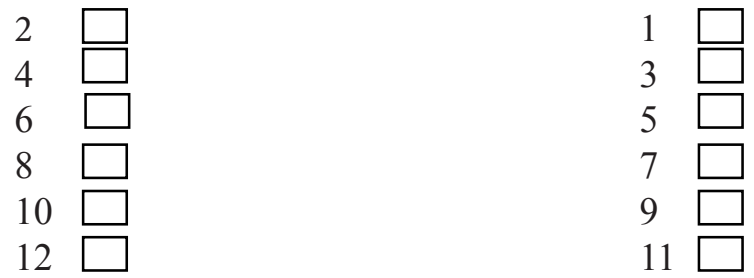

Pengeluduan 
Krama desa dalam struktur sosial di Tenganan Pegringsingan harus dalam keadaan utuh yang disebut dengan "bulu angkep" (suami-istri yang utuh). Keikutsertaan mereka dalam struktur sosial didasarkan sistem ulu apad (senioritas) berdasarkan waktu perkawinan. Pasangan mempelai yang lebih dulu kawin dianggap lebih senioritas dan berkedudukan lebih tinggi daripada mereka yang kawin belakangan. Kedudukan krama desa dalam struktur sosial di Desa Adat Tenganan Pegringsingan secara keseluruhan sebagai berikut :

(1) Lima orang yang disebut luwanan, yaitu krama No. 1 sampai dengan No. 5 menempati kedudukan paling atas dalam struktur sosial.

(2) Enam orang yang disebut bahan duluan, yaitu krama yang dimulai dari no. 1- 6 yang bertugas sebagai keliang desa .

(3) Enam orang yang disebut bahan tebenan, yaitu krama yang dimulai dari nomor 7- 12 sebagai calon pengganti keliang desa dan membantu bahan duluan .

(4) Dua belas orang yang disebut Tambalapu Roras, yaitu krama yang dimulai dari nomor 1 sampai nomor 12 yang bertugas menyampaikan perintah keliang desa secara bergilir setiap satu bulan sekali oleh 4 orang anggotanya.

(5) Krama desa pakraman dari nomor 1 berikutnya sampai habis yang disebut pengeluduan bertugas membantu keliang desa mencari perlengkapan sarana upacara keagamaan.

Bagi mereka yang menempati posisi sebagai kliang desa, tiap malam diwajibkan berkumpul di Bale Agung untuk membahas segala permasalahan yang belum terpecahan di desanya. Jika salah seorang anggota keliang desa yang laki-laki berhalangan hadir, bisa diwakili oleh istrinya. Akan tetapi jika permasalahan juga belum dapat diselesaikan akan diadakan sangkepan atau pertemuan desa lagi. Sangkepan ini hanya dihadiri oleh krama desa muani (anggota desa laki-laki) untuk membahas permasalahan yang belum dapat diselesaikan. Jika sangkepan juga tidak mencapai kesepakatan, rapat digelar kembali dengan mengundang kliang gumi, dan semua krama desa bulu angkep (pasangan suami istri). Semua pasangan suami istri mempunyai hak yang sama, dan pengambilan keputusan dilakukan dengan voting.

Dengan adanya perlakuan diskriminasi antara perkawinan endogamy dan eksogami, dan khawatir haknya sebagai krama desa hilang, orang tuanya selalu menasehati anaknya berharap agar tidak melakukan perkawinan antarwarga berbeda adat. Pelanggaran atas larang perkawinan eksogami semua hak-haknya sebagai warga masyarakat Tenganan Pegringsingan hilang termasuk tidak boleh duduk sebagai krama desa.

\section{Simpulan}

Masyarakat Desa Adat Tenganan Pegringsingan masih kental dengan perkawinan endogamy antar sesama warga adatnya sendiri. Perkawinan ini dianggap sebagai model perkawinan yang idial dan terhormat. Sebaliknya, perkawinan eksogami dilarang, dan dikenakan sanksi adat. Sanksi tidak hanya dijatuhkan kepada kedua mempelai, tetapi juga kepada orang tuanya.

Alasan-alasan sanksi adat pada perkawinan eksogami, yaitu pelestarian tradisi, menjaga sistem kekerabatan, dan menjaga kesehimbangan. Dalam konteks pelestarian tradisi, sanksi adat digunakan untuk menjaga dan memelihara serta melestarikan perkawinan endogami sebagai model perkawinan yang paling ideal, dan terhormat. Dengan pelestarian tradisi, keaslian unsur-unsur kebudayaan khususnya perkawinan endogami sesama warga adatnya tidak punah. Dalam konteks kekrabatan, sanksi adat digunakan untuk menjaga dan mempertahankan kemurnian sistem kekerabatan bilateral di desa adatnya. Dengan kekerabatan ini, kedua mempelai sama-sama setara kedudukannya di mata hukum. Artinya, kedua memepelai mempunyai hak yang sama sebagai ahli waris. Sebaliknya, dalam konteks kesehimbangan, sanksi adat dalam perkawinan eksogami 
digunakan untuk menjaga kesehimbangan tri hita karana, yaitu parahyangan, pawongan dan palemahan. Jika terjadi perkawinan eksogami, kesehimbangan terganggu karena warganya telah melakukan pelanggaran terhadap perkawinan eksogami sekaligus mencemari desanya.

Bentuk sanksi adat pada perkawinan eksogami adaduamacam, yaitusanksi dendadan sanksimoral. Terkait dengan sanksi denda, orang tua mempelai harus membayar uang dengan nominal Rp.18 000. Orang tua mempelai juga harus membayar uang tiap bulan sekali Rp.1000 selama hidupnya. Walaupun sanksi denda jumlahnya kecil, bukan berarti memberikan kebebasan kepada anaknya melakukan perkawinan eksogami melainkan hanya dilihat dari sisi kemanusiaan. Sebaliknya, dalam konteks sanksi moral, mempelai dan orang tuanya terbebani secara bathin karena perkawinan yang dilakukan merupakan perkawinan yang terlarang. Pelanggaran atas perkawinan tersebut juga diyakini membawa keletehan sehingga mempelai dan orang tuanya harus menanggung rasa malu selama hidupnya karena diyakini telah mencemari desa adatnya sendiri. Disamping itu juga orang tuanya dianggap tidak berhasil mendidik anaknya.

Implikasi sanksi adat pada perkawinan eksogami menunjukkan ketidakemansipasian, tidak memperoleh kesejahteraan dari desa adatnya, dan kehilangan semua hak-haknya di desanya. Dalam konteks ketidakemansipasian, warganya tidak diperbolehkan melakukan perkawinan tanpa dengan sesama warga adatnya sendiri. Pelanggaran atas larangan perkawinan eksogami dikenai sanksi adat. Dalam konteks tidak memperoleh kesjahteraan dari desa adatnya, warganya yang melakukan perkawinan eksogami tidak berhak menerima kesejahteraan dari desa adatnya. Dengan perkawinan eksogami, semua hak mempelai dicabut termasuk hak untuk memperoleh pembagian hasil dari desa adatnya. Dengan pencabutan ini, praktis mempelai tidak mendapatkan kesejahteraan karena kecuali mereka yang melakukan perkawinan endogami boleh menjadi krama desa. Krama ini memiliki hak istimewa di desanya. Sebaliknya, dalam konteks kehilangan semua hak-haknya di desanya, yaitu warganya yang melakukan perkawinan eksogami, semua hak-haknya dicabut sehingga mempelai sama sekali tidak memiliki hak di desanya atau tidak dianggap warganya lagi.

\section{Daftar Pustaka}

Al-Barry, M. Dahlan Yacub. 2000. Kamus Sosiologi-Antropologi. Surabaya : Indah.

Andreski, Stainlav. 1996. Marx Weber : Kapitalisme, Birokrasi dan Agama. Cetakan Kedua. Yogyakarta : Tiara Wacana.

Anonim. 2016. Undang-Undang HAM 1999. Jakarta : Sinar Grafika

Artayasa, I Nyoman dkk. 1998. Petunjuk Teknis Perkawinan Hindu. Surabaya : Paramita..

Astiti, Tjok Istri Putra. 2004. Nilai Anak dalam Kehidupan Keluarga Orang Bali dalam Bunga Rampai Sosiologi Keluarga. Jakarta : Yayasan Obor Indonesia.

Budiana, I Nyoman. 2004. "Rekonstruksi Perkawinan Eksogami di Tengah Perubahan Sosial di Bali”. Disertasi. Surabaya : Program Pascasarjana Universitas Airlangga.

2008. Perkawinan Beda Wangsa dalam Masyarakat Bali. Yogyakarta : Graha Ilmu.

Calyton, Richard. R. 1975. The Family, Marriage and Social Change. Lexington, Massachusetth, Toronto, London : D.C. Health and Company.

Covarrubias, Miguel. 1996. Island of Bali. New York : Knopf

Desa Pakraman Tenganan Pegringsingan, tt. Awig-awig Desa Tenganan Pegringsingan

Dharmayudha, I Made Suasthawa. 2001. Peranan Desa Pakraman dalam Menyelesaikan Kasus Adat. Denpasar : Biro Hukum Setda Propinsi 


\section{Bali}

Dharmayudha, I Made Suasthawa. dan Çantika, I Wayan Koti. 1991. Filsafat Adat Bali. Denpasar. Upada Sastra.

Friederich, R. 1959. The Civilization and Culture of Bali, Edited by Ernst R.Rost, Susil Gupta (India), Private Ltd.

Gorda, I Gusti Ngurah. 1996. Nilai-nilai Agama Hindu dan Etika Ekonomi Wirausahawan Bali. Disertasi. Denpasar : Surabaya : Universitas Erlangga.

Goris, R. 1954. Inscripties voor Anak Wungsu dalam Prasasti Bali. Jakarta : N.V.Masa Baru

Hobart, Mark. 1980. Ideas of Identity: The Interpretation of Kinship in Bali. Denpasar : Jurusan Antropologi Fakultas Sastra UNUD

Koentjaraningrat, 1992. Antropologi Sosial. Jakarta. Dian Rakyrat.

Majelis Pembina Desa Adat daerah Tk.I Bali. 1989/1990. Mengenal dan Pembinaan Desa Adat di Bali. Denpasar : Proyek Pemantapan Lembaga Adat Bali.

Majelis Pembina Desa Adat Daerah Tk.I Bali. 1992/1993. Desa Adat dan Kepariwisataan di Bali. Denpasar : Proyek Pemantapan Desa Adat.

Maswisnara, I Wayan. 1997.Bhagawad Gita. Surabaya : Paramita.

Polomo, Margareth M. 1992. Sosiologi Kontemporer. Jakarta: Rajawali Press.

Pudja, I Gde. 1973 Menawa Dharma Sastra. (Manu Dharma Sastra) atau Weda Sruti (Compendium Hukum Hindu). Jakarta : Direktorat jendral Bimbingan Masyarakat Hindu dan Budha

Pudja, Gede. 1975. Pengantar Hukum Perkawinan Menurut Hukum Hindu. Jakarta : Maya Sari.

Putra, Sudarma Ida Bagus. 2015. Hakikat Sanksi Adat Sangaskara Danda terhadap Pelanggaran Adat Gamia Gamana. Jurnal Magister Hukum Adat volume 4, No.2 Hal.205-424 Denpasar Bali Juli 2015, ISSN 2302-528X : Program Studi Magister (S2) Ilmu Hukum Program Pascasarjana Universitas Udayana.

Raka, Mas A.A. Gede, 2002. Perkawinan Yang Ideal. Surabaya : Paramita.
Saderson, Stephen K, 1993. Sosiologi Makro (Sebuah PendekatanTehadap Sosialitas Sosial), Cetakan Pertama. Jakarta : Rajawali Press.

Sujaya, I Made. 2007. Perkawinan Terlarang. Denpasar : Arti Foundation

Sudarma, I Putu. 2015. "Bias Gender dalam Perkawinan Bedawangsa pada Masyarakat Hindu Bali". Jurnal Harmoni No. 3 volome14 September-Dember 2015. Issn 1412-663 X. Jakarta:Puslitbang kehidupan Keagamaan Badan Litbang dan Diklat Kementerian Agama RI.

Sudarma, I Putu.2012. Perkawinan Nyeburin di Tengah Perubahan Sosial di Kabupaten Tabanan. Disertasi. Denpasar. Program Pascasarjana Universitas Udayana

Suja, I Wayan. 1999. Tafsir Keliru terhadap Hindu. Denpasar : Yayasan Dharma Naradha.

Surpha, I Wayan. 2002. Seputar Desa Pakraman dan Adat Di Bali. Denpasar : PT. Ofsset BP.

Tim Penyusun. 1993. Kamus Besar Bahasa Indonesia. Jakarta : Balai Pustaka

Tim Penyusun. 2008. Kamus Bali-Indonesia. Yogyakarta : Yayasan Pustaka Nusatama.

Tim Penyusun. 2010. Wicara Lan Pamidanda. Denpasar. University Press.

Wiana, I Ketut dan Raka Santri. 1993. Kasta dalam Hindu : Kesalahpahaman Berabadabad. Cetakan Pertama. Denpasar : Yayasan Dharma Naradha.

Wiana, I Ketut.2006. Memahami Perbedaan Catur Warna, Kasta dan Wangsa. Surabaya : Paramita.

Widana, I Gusti Ketut. 1997. Menjawab Pertanyaan Umat Yadnya Sesa Pemborosan. Denpasar : Yayasan Dharma Narada.

Windia. I Wayan. 2008. Bali Mawacara. Denpasar : Udayana University Press

Windia. Wayan. 2003. Danda Pacamil. Denpasar : Upadasastra.

Wisnumurti, Anak Agung Gede Oka. 2010. "Dinamika Politik Lokal dalam Pemilihan Kepala Daerah Langsung 2005 di Kabupaten Badung” Disertasi. Denpasar : Program Pascasarjana Universitas Udayana. 